https://doi.org/10.19195/0524-4544.333.20

\author{
IRENA LIPOWICZ \\ ORCID: 0000-0001-6794-6683 \\ Uniwersytet Stefana Kardynała Wyszyńskiego w Warszawie \\ i.lipowicz@uksw.edu.pl
}

\title{
Ewolucja postrzegania statusu ustrojowego uniwersytetu na tle poglądów Tadeusza Bigi
}

\begin{abstract}
Abstrakt: Przedmiotem opracowania jest rozważenie ewolucji instytucji Uniwersytetu na tle ostatnich zmian stanu prawnego w tym zakresie, w konfrontacji z klasyczną postacią zakładu samorządowego o charakterze samoistnym, konstrukcji wypracowanej w 1928 roku przez Tadeusza Bigę. Uniwersytet ujmowany był wtedy jako zakład publiczny, wspólnota uczonych i uczących się. Fascynacja efektywnością, podejściem menadżerskim typowym dla korporacji, w końcowych latach XX wieku oznaczała stopniowe odchodzenie od wizji Uniwersytetu jako przestrzeni wolności, autonomii akademickiej, kreatywności i samodzielności - uznanej formy decentralizacji.

W opracowaniu wskazano, na tle zróżnicowanych poglądów doktryny, na formę zakładu publicznego jako stopniowe ukształtowanie się przeważającego poglądu na uniwersytet $\mathrm{w}$ tym zakresie. Analizie poddano skutki prawne odchodzenia od uniwersalnej konstrukcji uniwersytetu na rzecz przyszłego dualizmu uczelni akademickich i zawodowych. Postępujące ograniczanie ich samodzielności następuje między innymi przez mnożenie mierników, wskaźników i ewaluacji, a także standaryzacji, formalnej punktacji osiągnięć naukowych. Uniwersytet, odmiennie niż w koncepcji Tadeusza Bigi, stał się „wyrazem zastrzeżonym” dla nazwy jednego z wielu rodzajów uczelni. Konkluzją artykułu jest wyrażenie przekonania o teoretycznej nośności i dalszej praktycznej przydatności omówionej uniwersalnej konstrukcji uniwersytetu jako pośredniej formy między korporacją a zakładem administracyjnym — zaproponowanej niegdyś przez Tadeusza Bigę — oraz wskazanie deficytów nowych rozwiązań legislacyjnych w odniesieniu do przyszłych zadań uniwersytetu, w czasach zarządzania w warunkach niepewności i kluczowej roli tworzenia środowiska sprzyjającego kreatywności i innowacjom.
\end{abstract}

Słowa kluczowe: uniwersytet, uczelnia, zakład publiczny, zakład administracyjny, zakład samorządowy, decentralizacja. 


\section{Uwagi wstępne}

Uniwersytet jest najczęściej opisywany jako wspólnota uczonych i uczących się oraz innych pracowników uniwersytetu, jako klasyczny zakład publiczny. To jedna $\mathrm{z}$ ważnych form decentralizacji, której częścią niezbywalną jest zagwarantowana w ustawie samodzielność, a także ingerencja organu nadzorującego — „punktowa" - występująca w przypadkach i formach przewidzianych prawem. Od tej klasycznej formy mającej swoje korzenie w odległym średniowieczu i w czasie kształtowania pierwszych uniwersytetów włoskich Bolonii i Padwy, przeszliśmy długą drogę. Fascynacja efektywnością, prywatyzacją, podejściem menadżerskim końca XX wieku doprowadziła — z punktu widzenia klasycznej nauki prawa administracyjnego - do swoistej ruiny ideału uniwersytetu jako wyjątkowej wspólnoty, azylu i oazy wolności ${ }^{1}$. Można postawić pytanie, czy koszty tej przemiany nie przewyższają korzyści? W tym celu warto spojrzeć na nią z szerszej perspektywy.

Przedmiotem niniejszego opracowania jest rozważenie ewolucji postrzegania statusu ustrojowego uniwersytetu na tle poglądów profesora Tadeusza Bigi. Oczywiście podstawową pracą w tym zakresie jest monografia o związkach publicznoprawnych $^{2}$ (z wydawnictwa kasy imienia Mianowskiego, z zasiłku Ministerstwa Wyznań Religijnych i Oświecenia Publicznego) wydana w 1928 roku. Warto podkreślić tę datę, albowiem to dopiero siedem lat po Konstytucji marcowej, okres początkowy kształtowania się samodzielnej polskiej doktryny, już nie podzielonej jak uniwersytety w państwach zaborczych, ale rozwijanej w warunkach niepodległego kraju. Refleksją tą od początku objęty był także sam uniwersytet ${ }^{3}$ jako instytucja prawna. Tadeusz Bigo w przedmowie wskazuje, że studium na podstawie prawa polskiego mogło się wtedy spotkać z zarzutem, że jeszcze za wcześnie na taką pracę, skoro obok prawa polskiego obowiązywały wciąż jeszcze obce systemy prawne. Autor skromnie stwierdza, że nie rości sobie pretensji do syntezy, chce raczej ułatwić i przygotować następne badania.

Charakteryzując związki publicznoprawne - główny temat książki, do których to związków nie zaliczał uniwersytetów - Bigo wypowiadał się równocześnie stanowczo przeciwko redukowaniu administracji do działalności organów administracji państwa, to znaczy administracji rządowej ${ }^{4}$. Bigo stwierdzał, że jeśli chcemy wyjść poza tę formułę, musimy poprzestać na kryterium środków działania. Administracja publiczna to działalność, która realizuje prawo przy pomocy przymusu bezpośredniego (sankcje stosowane bez ingerencji sądów). Równocześnie podkreślał, że podmioty wykonujące administrację publiczną mogą w pewnym zakresie obchodzić się bez tego władztwa i działać przy pomocy środków

1 A. Bloom, Umyst zamknięty. O tym, jak amerykańskie szkolnictwo wyższe zawiodło demokrację i zubożyto dusze dzisiejszych studentów, Poznań 2007, passim.

2 T. Bigo, Związi publiczno-prawne w świetle ustawodawstwa polskiego, Warszawa 1928.

3 B. Wasiutyński, Samorząd uniwersytecki, „Przegląd Prawa i Administracji” 4, 1926, s. 422 n.

4 T. Bigo, op. cit., s. 118. 
zwyczajnych, to jest podlegających kontroli i realizacji rzez sąd. Z tego wyrosło wczesne - nawiązujące do klasycznej formuly Otto Mayera ${ }^{5}$ - ujęcie administracji przez autora; przy stwierdzeniu, że jest to działalność państwa (z wyłączeniem wymiaru sprawiedliwości i prawodawstwa) oraz związków publicznoprawnych i innych podmiotów stosujących przymus bezpośredni. Charakterystyczne, że Bigo podkreśla, co czasem było niedostrzegane w naszej doktrynie, iż związki publicznoprawne są jednym z typów decentralizacji i dają się teoretycznie oddzielić, nie tylko od administracji państwowej, ale także od innych typów administracji zdecentralizowanej dla wyznaczenia ich miejsca (zwróćmy uwagę na wczesne użycie tego pojęcia w Systemie Administracji Publicznej $\left.{ }^{6}\right)$.

Decentralizacja ,prawno-administracyjna”, widziana przez autora w 1928 ro$\mathrm{ku}$, to taki system, w którym istnieje większa liczba ośrodków administracji publicznej. Od decentralizacji odróżnia autor, w sposób do dziś aktualny, dekoncentrację, którą charakteryzuje „zróżniczkowanie w łonie samej administracji [...], ale źródłem jedynem działalności administracyjnej pozostaje — rząd"7. Należy podkreślić ważne słowa: „nie jest decentralizacją sam podział kompetencji między poszczególne resorty ministerjalne, bo ponad niemi niema innego wyższego źródła

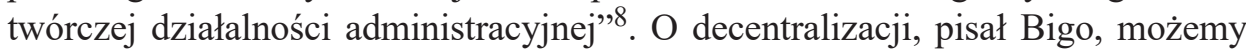
mówić wtedy, gdy podmioty administrujące ,samodzielnie rozwijają realizację norm ustawowych". Kluczową kategorią w państwie pozostaje porządek hierarchiczny, charakterystyczny dla dekoncentracji. Silnie podkreślono cechę decentralizacji jako takiego systemu administracji, przy którym podmioty administrujące mają samodzielność w stosunku do centralnej władzy ${ }^{9}$. Bardzo mocno uwydatniał jednak autor odrębność swojego poglądu na decentralizację w polskiej doktrynie; od początku za błędne uważał on utożsamianie decentralizacji tylko z samorządem. Samorząd to bowiem tylko jeden z typów decentralizacji, która jest pojęciem

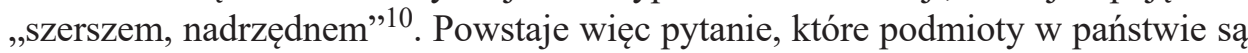
wystarczająco samodzielne w świetle prawa, aby uznać je za podmioty zdecentralizowane, a równocześnie nie są samorządami ani terytorialnymi, ani zawodowymi?

\section{Uniwersytet jako zakład administracyjny}

Zakład administracyjny, jakim ma być uniwersytet w ujęciu Tadeusza Bigi, pozwala ująć element korporacyjny — fakt, że uniwersytet stanowi wspólnotę

${ }^{5}$ O. Mayer, Deutsches Verwaltungsrecht, Leipzig 1895, t. 1, s. 9.

${ }^{6}$ M. Stahl, Zagadnienie ogólne, [w:] System Prawa Administracyjnego, t. 6. Podmioty administrujące, red. R. Hauser, Z. Niewiadomski, A. Wróbel, Warszawa 2011, s. 28 n.

7 Ibidem, s. 121.

${ }^{8}$ Ibidem.

${ }^{9}$ Ibidem, s. 123.

10 Ibidem, s. 124. 
ludzi uczących i nauczanych posiadających oprócz samodzielności zagwarantowanej ustawą środki majątkowe, ruchome i nieruchome, określane dzisiaj chętnie jako infrastruktura, a także posiadające gwarancje finansowania ze strony państwa. Wyposażone są one w zdolność wydawania norm wewnętrznych, wiążących dla całej wspólnoty uniwersytetu, a w wyjątkowych przypadkach dla osób spoza uniwersytetu; typowym przykładem samodzielności normowanej w klasycznej organizacji uniwersytetu pozostaje statut. Jest rzeczą charakterystyczną, że w całej doktrynie przełomu XX i XXI wieku w Polsce przyjęła się linia teoretyczna Tadeusza Bigi. Była ona już zresztą przyjęta w szerokim rozumieniu decentralizacji wcześnie, bo przez Jerzego Starościaka w latach siedemdziesiątych XX wie$\mathrm{ku}$ - w warunkach ustrojowych PRL, skrajnie wrogich decentralizacji. Myśl, że samorząd terytorialny i samorządy zawodowe zdecydowanie nie wyczerpują — istniejących w polskim porządku prawnym okresu międzywojennego — form decentralizacji, okazała się więc trwałym i ważnym dorobkiem naukowym, niezależnym od wstrząsów ustrojowych i panujących przez lata praktyki.

Czy po wielu latach od śmierci Tadeusza Bigi, który wraz z Franciszkiem Longchamps'em położył podwaliny szkoły wrocławskiej prawa administracyjnego, możemy mówić o tym, że również teoria uniwersytetu jako ważnej formy decentralizacji była w naszej doktrynie wystarczająco rozwijana; a przede wszystkim czy w swoim obecnym kształcie ustrojowym wyznaczonym ustawą $^{11}$ z 2018 roku uniwersytet nadal stanowi formę decentralizacji? Czy możemy mówić o wystarczającym utrzymaniu korporacyjnego substratu uniwersytetu oraz o wystarczająco silnym zaakcentowaniu jego samodzielności? Podobne pytanie można by postawić także $\mathrm{w}$ odniesieniu do muzeum publicznego, uważanego również za klasyczną formę decentralizacji ${ }^{12}$. I w tym przypadku w ostatnich latach obserwujemy swoiste "zagęszczenie" prawa materialnego z silną tendencją do sprowadzania muzeum do roli zbliżonej do PRL-owskiej „placówki kulturalnej” (państwowej jednostki organizacyjnej kultury). Przez lata bowiem, jak wskazano w komentarzu, ulegała wzmocnieniu pozycja prawna Ministra (właściwego do spraw kultury) wobec muzeum publicznego, a osłabiano pozycję prawną występujących w muzealnictwie kolegialnych organów doradczych.

Jaka idea leżała u podstaw organizacji uniwersytetu, i to w jego klasycznej pruskiej humboldtowskiej formie, jako jednostki korporacyjnej obdarzonej pewną samodzielnością? Duchowi państwa pruskiego o wiele bardziej odpowiadała przecież ścisła hierarchia i silne podporzadkowanie; oczywiście istotna była niemiecka tradycja silnych uniwersytetów lokalnych o sięgającej średniowiecza autonomii, oraz rola prawników (i ogólnie akademików) w pruskiej administracji publicznej. Nawet jednak tam rozumiano pożytki płynące z kultywowania pewnej

11 Ustawa z dnia 20 lipca 2018 roku — Prawo o szkolnictwie wyższym i nauce (Dz.U. z 2021 r. poz. 478).

12 Por. Z. Cieślik et al., Komentarz do ustawy o muzeach, Warszawa 2021. 
ograniczonej autonomii ${ }^{13}$. Wyodrębnienie w państwie, nawet tak hierarchicznym, pewnych enklaw samodzielności i swobody, również w zamiarach Wilhelma von Humboldta — tak różnego przecież w poglądach od swojego brata Aleksandra miało także swój państwowotwórczy sens ${ }^{14}$, budowało siłę państwa.

\section{Samoistność zakładu publicznego}

Rozważyć z kolei należy, jak postrzegał Tadeusz Bigo w polskim systemie prawnym szkoły akademickie. Wychodził on w tej analizie od pojęcia samoistnych zakładów publicznych; określił je także jako formę decentralizacji, która „zajmuje dość poczesne miejsce w polskim systemie"15. Samoistność ową zakład publiczny uzyskuje przez nadanie osobowości prawnej ${ }^{16}$, jednakże zakłady jako osoby prawne generalnie przeciwstawia Bigo korporacjom.

W czytelny sposób wskazywał bowiem, że podczas gdy w korporacji organizacja stanowi dzieło jej członków (grupy działającej), to w zakładzie jest ona - jak stwierdzał- „oktrojowana przez osobę trzecią: albo państwo albo publicznoprawny związek samorządowy (związek macierzysty)”. To od „związku macierzystego" pochodzi statut zakładu, a także z reguły substrat osobowy, zatem osoby mające działać w imieniu zakładu. Zakłady państwowe otrzymują statut w formie ustawy, czasem do jego zmiany dopuszczony jest zarząd zakładowy razem z władzą nadzorczą. W korporacji publicznoprawnej — podkreślał Bigo jest „swoisty akt konstytucyjny”, który pochodzi od osoby trzeciej (państwa albo od członków korporacji i państwa). Zasadniczą różnicę postrzegał autor w tym, że członkowie korporacji publicznoprawnej mają zawsze udział w tworzeniu organów, tymczasem w zakładzie osoby działające w jego imieniu jako organy są powołane i ustanowione przez osobę trzecią — „związek macierzysty”. Dopuszczalny, co szczególnie ważne, z punktu widzenia niniejszych rozważań jest typ pośredni, a więc takie zakłady publiczne, w których substrat osobowy lub destynatariusze mają udział w tworzeniu organizacji. Powoduje to bowiem, że powstaje „pośredni typ strukturalny” o charakterze mieszanym (zakładowo-korporacyjny). Tą formą mieszaną są w szczególności zakłady o charakterze korporacyjnym zwane zakładami samorządowymi. W polskim systemie prawnym zaliczał do nich Tadeusz Bigo właśnie szkoły akademickie. Podkreślał przy tym jako rzecz najcie-

13 https://www.rp.pl/Plus-Minus/303029925-Kosmos-Humboldta-Jak-zapomnielismy-o-niemieckim-geniuszu.html (dostęp: 30.01.2022).

14 I. Zakowicz, Idea uniwersytetu Wilhelma von Humboldta - kontynuacja czy zmierzch?, „Ogrody Nauk i Sztuk” 2012, nr 2.

15 T. Bigo, op. cit., s. 196.

16 Ibidem, s. 179. 
kawszą, że według ówczesnego prawa ${ }^{17}$ udział w tworzeniu organów mieli tylko członkowie ciała profesorskiego, choć jak należy rozumieć, byłoby logiczne, gdyby byli to też destynatariusze (studenci). To samo dotyczy statutu uniwersytetu.

Mimo odrębności korporacyjnych autor nie kwestionował charakteru zakładowego uniwersytetu i uważał za sukces przyjęcie tego jako powszechnie panującego poglądu. Uniwersytet ma być ściślej zespolony z organizmem administracyjnym państwa „niż jakikolwiek związek publicznoprawny”18.

Na podstawie ówczesnego prawa profesorowie uniwersytetu byli jeszcze właściwie urzędnikami państwowymi. Mimo że w latach dwudziestych XX wieku na tle ustawodawstw zaborczych kwestionowano jeszcze samoistność uniwersytetu, to jest jego podmiotowość publicznoprawną, opowiedział się nasz autor za przyznaniem uniwersytetowi takiej samoistności. Przypomnieć należy jeszcze te cechy, które Bigo uznał ogólnie za podstawowe cechy zakładu publicznego. Kryterium ma być „,moment celu”, który pozwala odróżnić zakład od przedsiębiorstwa; o ile bowiem zakład służy trwale celowi administracji publicznej, przedsiębiorstwo zmierza do pomnożenia zysku, choć może także służyć celom administracji publicznej. Oryginalne było kryterium proponowane przez Bigę: przedsiębiorstwo może być samodzielne lub niesamodzielne pod względem prawnym ${ }^{19}$, podobna jest także forma powstania stosunku użytkowania. Autor podkreślał, że zakład rozporządza środkami szczególnymi: władztwem zakładowym i policją zakładową. Uważał też, że trzeba przyznać uniwersytetowi samoistność.

\section{Elementy pojęcia zakładu}

Istotnym elementem definiowania zakładu pozostaje władztwo zakładowe, które polega w ujęciu autora na jednostronnym regulowaniu stosunku użytkowania - stosunku do destynatariusza. Bigo odróżniał władztwo zakładowe od policji zakładowej, podążając w tym zakresie za nauką niemiecką. O ile władztwo dotyczy użytkowników, o tyle policja zakładowa osób trzecich, wyraża się ona z reguły w aktach o treści negatywnej, a więc jak pisał autor: „mających na celu usuwanie wszystkiego co by mogło być przeszkodą w normalnem funkcjonowaniu zakładu. W jednym i drugim zakresie zakład używa bezpośredniego przymusu administracyjnego" ${ }^{20}$. Przyjęcie koncepcji odmiennej od ówczesnego ujęcia doktryny francuskiej, że decentralizacja nie wyczerpuje się w samorządzie terytorialnym, ale posiada również inne formy (wśród nich autor charakteryzował między innymi uzdrowiska i ich organy), było doniosłą opcją na rzecz klasycznego ujęcia

17 Ustawa z dnia 13 lipca 1920 roku o szkołach akademickich (Dz.U. Nr 72, poz. 494).

18 T. Bigo, op. cit., s. 198.

19 Ibidem, s. 200.

20 Ibidem. 
podobnego do doktryny niemieckiej. Doktryna ta następnie w latach trzydziestych XX wieku ulegnie znaczącej erozji pod wpływem ideologii faszystowskiej. Fascynację tym kierunkiem spośród polskich teoretyków wykazał niestety Jerzy Panejko ${ }^{21}$, Tadeusz Bigo trwał do końca przy klasycznej koncepcji władztwa i podstawowych wartościach samorządu i demokracji, choć jeszcze w roku 1928, w pracy o związkach publiczno-prawnych, żywił złudzenia co do pozytywnych kierunków przyszłego rozwoju nauki niemieckiej.

Pozwoliło to ujęcie szerzej pojmować polski system decentralizacji i ugruntować teorie samoistnego zakładu publicznego, z jego szczególną formą — uniwersytetem. Osobowość prawna i ekskluzywność charakteru publicznego „charakterystyczna dla samoistnego zakładu publicznego" łączy go ze związkiem publicznoprawnym, łączy je także władztwo administracyjne.

Renata Raszewska-Skałecka w artykule Zakłady zwraca uwagę na zasługi Tadeusza Bigi dla definiowania pojęcia zakładu, autorka podkreśla rozróżnienie zakładów publicznych samoistnych i typów mieszanych, a także samoistnych zakładów publicznych o charakterze mieszanym. Autorka wskazuje, że pogląd ten nie stracił na aktualności i podnoszony jest we współczesnej literaturze przedmiotu — jako łączący status zakładu administracyjnego z formułą korporacyjną. Mimo więc prób definiowania szkoły wyższej jako korporacji prawa publicznego dominuje ujęcie uniwersytetu jako zakładu, odwołujące się do kryterium wyodrębnienia szkoły wyższej jako samodzielnego podmiotu administracji z osobowoscią prawną wydzielonego z ogólnej organizacji; wyraźną kontynuacją była tu monografia Wita Klonowieckiego ${ }^{22}$. Autorka zasadnie podnosi podobieństwo a równocześnie ewolucję poglądów w doktrynie międzywojennej i pogląd Klonowieckiego na tym tle — o samoistnych zakładach publicznych; takich, które mają sprawować funkcje administracji publicznej samodzielnie, nie podlegają władzy hierarchicznej organów administracji rządowej ${ }^{23}$, są zatem jedną z form decentralizacji. Dyskusyjne jest, na ile był to wpływ doktryny francuskiej, która również postrzega zakład publiczny jako formę decentralizacji — na co wskazuje Renata Raszewska-Skałecka. Tadeusz Bigo i Wit Klonowiecki dokonali więc w swojej pracy pewnej twórczej syntezy wpływów francuskich i niemieckich ${ }^{24}$.

Również Stanisław Kasznica ${ }^{25}$ akcentował jedność organizacyjną zakładów i związanie ze ściśle określonym celem. Często mylnie następuje odwoła-

21 Por. J. Dobkowski, Podmiotowość prawna samorząu terytorialnego w świetle pogladów Jerzego Karola Panejki, [w:] M. Stec, K. Małysa-Sulińska, Podmiotowość samorzadu terytorialnego-ustrojowe pytania i dylematy, Warszawa 2020, s. 296-297, 303.

22 W. Klonowiecki, Zakład publiczny w prawie polskim studium prawno-administracyjne, Lublin 1933, s. $121 \mathrm{n}$.

23 Ibidem, s. 221.

24 R. Raszewska-Skałecka, Zakłady, [w:] Tadeusz Bigo o administracji i prawie administracyjnym - refleksje wroctawskiej szkoty administratywistycznej, red. T. Kocowski, P. Lisowski, M. Paplicki, Wrocław 2020, s. 19.

25 S. Kasznica, Polskie prawo administracyjne, Warszawa 1947, s. 13 n. 
nie do diagnozy „pewnej dozy samodzielności” zakładu, którą Bigo określał jako „mieszczącą się w ramach dekoncentracji”. Dotyczyło to jednak wyłącznie zakładów niemających charakteru samoistnego ani osobowości prawnej; pozostałe zakłady są formą decentralizacji, a jej istota wyraża się — jak akcentował to Bigo - w wydzieleniu części majątku narodowego i oddania go we względnie samodzielny zarząd, utworzonym w tym celu organom ${ }^{26}$. W szczególności należy podkreślić kwestię samodzielności oraz zgodzić z poglądem autorki, że Tadeusz Bigo zapoczątkował w tym zakresie trwały kierunek doniosłych, teoretycznych badań szkoły wrocławskiej.

\section{Inspiracja dla współczesności}

W monografii Tadeusza Bigi uwagi o samoistnych zakładach publicznych stanowią kwestie uboczną, może być ona jednak dla nas bardzo inspirująca w stawianiu pytań o dalsze losy zakładu publicznego, takiego jak uniwersytet czy muzeum. W badaniach nad decentralizacją koncentrowano się przez ostatnie trzydzieści lat $\mathrm{w}$ naturalny sposób na samorządzie terytorialnym - było to $\mathrm{w}$ pełni zrozumiałe w świetle burzliwych zmian ustrojowych. Zakład publiczny od czasu klasycznych monografii Marka Elżanowskiego ${ }^{27}$ i Eugeniusza Ochendowskie$\mathrm{go}^{28}$ był przez długie lata co do swej istoty postrzegany praktycznie niezmiennie, choć nowsze monografie wniosły wiele ważnych ustaleń. Nie kwestionowano także tego, że uniwersytet mimo pewnych osobliwości ustrojowych i funkcjonalnych pozostaje samoistnym zakładem publicznym, zakładem samorządowym, w którym jednak ,profesorowie”, jak ich określał Bigo, nie są już (jak to pojmowano na początku XX wieku) prawie identyczni z urzędnikami państwowymi, ale stanowią ,personel” samoistnego zakładu.

Autonomia uczelni, ograniczenia we wkraczaniu sił porządkowych, wewnętrzne władztwo i samorząd uczelni trwały na zachodzie Europy przez lata prawie niezmiennie. W krajach Unii Europejskiej występowały z jedną korzystną zmianą: w pełni uzasadnione było już włączenie studentów i innych niż profesorowie pracowników uczelni do współdecydowania. Zmiana ustroju w Polsce w 1989 roku poszerzyła wolności akademickie.

Ostatnie radykalne zmiany ustawowe w Polsce, dotyczące szkolnictwa wyższego, każą jednak postawić pytanie, dokąd zaprowadziła nas ewolucja postrzegania statutu ustrojowego uniwersytetu. Czy Tadeusz Bigo rozpoznałby jeszcze

${ }^{26}$ R. Raszewska-Skałecka, op. cit., s. 192. Szerzej o rozwoju szkoły wrocławskiej piszę w: Sytuacja prawna człowieka wobec administracji publicznej w pogladach Franciszka Longchamps, „Państwo i Prawo” 2019, nr 5.

27 M. Elżanowski, Zakład państwowy w polskim prawie administracyjnym, Warszawa 1970.

28 E. Ochendowski, Zakład administracyjny jako podmiot administracji państwowej, Poznań 1969. 
w tej instytucji ów „samoistny zakład samorządowy” — formę pośrednią pomiędzy klasycznym zakładem publicznym a samorządem terytorialnym? Czy obecne rozumienie wykonywania $\mathrm{w}$ tym obszarze władztwa administracyjnego odpowiada jeszcze klasycznym fundamentom polskiej nauki prawa administracyjnego, którą tak doskonale w swoich dziełach uosabiał Tadeusz Bigo?

Jak bardzo użyteczne jest obecnie, w latach dwudziestych XXI wieku, w świetle realizacji wartości konstytucyjnych i zasad prawa administracyjnego, postrzeganie uniwersytetu jako przestrzeni wolności, autonomii, ale też władztwa zakładowego i policji zakładowej, wspólnoty uczonych, studentów i innych pracowników uczelni? Po cóż nam jeszcze w ogóle taka szczególnie chroniona przestrzeń badań i wolności akademickiej? Takie pytanie stawiano zwłaszcza pod naciskiem teorii New Public Management (Nowego Zarządzania Publicznego, w skrócie określanego jako NPM), w okresie swoistej apoteozy prywatyzacji i rozliczania uniwersytetów z krótkoterminowej efektywności, publikacji i punktów. Ten trend, który już przemija w starych krajach Unii Europejskiej, w Polsce - jak się wydaje — osiąga swoje apogeum. Uniwersytet ze swoimi z natury wysokimi kosztami działania może być irytujący dla zwolenników radykalnej redukcji wydatków publicznych oraz skrajnej ekonomizacji wszystkich instytucji publicznych. Można przypuszczać, że wielu najwybitniejszych światowej klasy uczonych europejskich XIX i XX wieku musiałoby opuścić uczelnię długo przed swoimi sukcesami, nie mogąc się wykazać odpowiednią liczbą punktów i sukcesów nadających się do sprawozdań i wysoko punktowanych publikacji.

Z drugiej strony można stwierdzić, że zmiana pozycji prawnej uniwersytetu to jeden z pierwszych przykładów administracji opartej na wiedzy. Mamy przecież szereg obiektywnych mierników, takich jak indeksy cytowań oraz szczegółowa sprawozdawczość, które pozwalają obiektywizować osiągnięcia. Silniej niż w poprzednich latach rozliczane jest także, zgodnie z polskim prawodawstwem, działanie na rzecz otoczenia społeczno-gospodarczego. Również ono zostało wtłoczone w system mierników i sprawozdań, czasami jednak naturalne oddziaływanie uniwersytetu lub innej uczelni na całe otoczenie, zwłaszcza w mniejszych ośrodkach, nie jest łatwo mierzalne, ale na pewno pozostaje kulturo- i miastotwórcze.

\section{Uniwersytet $\mathrm{w}$ procesie zmian. Ku dominacji pojęcia uczelni?}

Przejdźmy od poglądów Tadeusza Bigi na temat uniwersytetu jako — nadal — publicznej szkoły wyższej, czyli uczelni (w świetle ostatnich zmian ustawodawczych), do analizy obecnej pozycji prawnej tego podmiotu. W końcowej części artykułu pozwoli to na ocenę, jak daleko zaprowadziła nas ewolucja postrzegania statusu ustrojowego uniwersytetu ukazana na tle poglądów Bigi. 
Od prostej konstrukcji zakładu administracyjnego, jakim był uniwersytet w latach dwudziestych i trzydziestych XX wieku (politechnika, akademia medyczna lub akademia sztuk pięknych), przechodzimy w legislacji do skomplikowanego systemu, który został określony przez obowiązującą ustawę - Prawo o szkolnictwie wyższym i nauce z 2018 roku, a w którym podstawową kategorią staje się uczelnia podzielona na dwa rodzaje: uczelni akademickiej i zawodowej. Uczelnie akademickie publiczne i niepubliczne zostały obarczone szeregiem zadań określonych w dziesięciu kategoriach, ale zadania te są podstawowe jedynie dla uczelni akademickiej; uczelnia zawodowa otrzymuje dodatkowo ,prowadzenie kształcenia specjalistycznego" (art. 15 ust. 2 w zw. z ust. 4), natomiast traci — jako podstawowe — prowadzenie działalności naukowej, świadczenie usług badawczych, a także prowadzenie kształcenia doktorantów, a więc elementy uważane poprzednio za nieodłączne dla uniwersytetu i instytucji pokrewnych.

W nowej ustawie z 2018 roku odnajdujemy oczywiście pojęcie uniwersytetu, jest przy tym pouczające to, jak zostaje on określony w art. 16 ust. 1. Jest to po prostu obecnie wyraz zastrzeżony dla nazwy uczelni akademickiej posiadającej kategorię naukową $\mathrm{A}+, \mathrm{A}$ albo $\mathrm{B}+\mathrm{w}$ co najmniej sześciu dyscyplinach naukowych lub artystycznych zawierających się w co najmniej trzech dziedzinach nauki lub sztuki, a politechnika to także wyraz zastrzeżony dla nazwy uczelni akademickiej posiadającej kategorię naukową $\mathrm{A}+$, A albo B+ w co najmniej dwóch dyscyplinach $\mathrm{w}$ zakresie nauk inżynieryjnych i technicznych (art. 11 ust. 2). Charakterystyczne zresztą, że uniwersytet umieszczono w art. 16 dopiero w trzeciej kolejności, po scharakteryzowaniu definicji legalnej akademii i politechniki. Spójrzmy więc, jak „głęboko” musimy szukać obecnie w ustawie klasycznego uniwersytetu. To rodzaj uczelni, ale nie każdej, tylko akademickiej, i wreszcie nie każdej akademickiej, ale tylko takiej, która spełnia wyśrubowane warunki w zakresie kategorii naukowych. Uniwersytet nie jest już jednak nazwą zastrzeżoną dla uczelni publicznej — może to być także uczelnia niepubliczna. To niezwykła redukcja dotychczasowego szerokiego pojęcia publicznego samorządowego zakładu, tak jak go postrzegał Bigo. Autonomia, samorządność, kreowanie pewnej zamkniętej wspólnoty o dużym stopniu samodzielności i władztwie zakładowym ulega znaczącej erozji. Świadczy o tym chociażby art. 22 ust. 1, stanowiący, że przewodniczącym ważnego organu uczelni, jakim jest Rada Uczelni, musi być członek pochodzący spoza wspólnoty uczelni, choć wybrany przez Senat. Pozostałością elementów samorządowych jest z kolei obligatoryjne wejście w skład Rady Uczelni przewodniczącego samorządu studenckiego.

Rada Uczelni jest więc w istocie organem hybrydowym o niejasnym charakterze prawnym z punktu widzenia celów ustawy. Kilka ważnych kompetencji, takich jak wskazywanie kandydatów na rektora czy zatwierdzenie sprawozdania finansowego (art. 18 ust. 1), które wskazywałyby na kierownictwo, a przynajmniej nadzór, jest otoczona kompetencjami w większości opiniodawczymi oraz obo- 
wiązkiem składania Senatowi rocznego sprawozdania z działalności. Rada uczelni jest zresztą przez Senat wybierana, ale i tutaj następuje zasadnicze przełamanie wizji uniwersytetu jako „samorządzącej się wspólnoty”. Osoby spoza tej wspólnoty stanowić muszą co najmniej $50 \%$ osób powoływanych przez Senat. Ważnym elementem konstrukcji zakładu administracyjnego o charakterze samorządowym była też zawsze duża rola organów kolegialnych w zarządzaniu tą wspólnotą. Obecnie obowiązująca ustawa zrywa z tą tradycją, większość ciężaru zarządzania uczelnią przejmuje Rektor i wspierający go Senat. W wielu uczelniach tradycyjne Rady Wydziału albo zaniknęły, albo funkcjonują obok o wiele obecnie silniejszej kompetencyjnie Rady Dyscypliny Naukowej. Ciągle jeszcze ważną rolę odgrywa statut określający na przykład skład kolegium elektorów uczelni publicznych oraz tryb wyborów jego członków. Studenci i doktoranci obligatoryjnie stanowią 20\% jego składu. Rektor uczelni publicznej może być powołany lub odwołany; warto przyjrzeć się możliwości odwołania, która, choć znacznie ją utrudniono (większość co najmniej trzech czwartych głosów quorum dwóch trzecich statutowego składu), podnosi rangę kolegium elektorów.

Ogólnie można jednak stwierdzić, że generalnie decentralizacja wewnętrzna uczelni ustępuje już w ustawie z 2018 roku miejsca dekoncentracji. Nawet jeżeli przewidziano także obligatoryjny udział innych członków wspólnoty akademickiej niż profesorowie, a swoje miejsce w organach uczelni mają także studenci i doktoranci oraz „młodsi” nauczyciele akademiccy, oraz inni pracownicy uczelni — to ogólna tendencja wydaje się jasna. Jest ona dodatkowo wzmocniona tym, że Rektor jest nadal ex lege przewodniczącym Senatu. W najbliższych latach będziemy przeżywali swoistą „,degradację” części uczelni do pozycji uczelni zawodowych publicznych i niepublicznych. Będzie się to łączyło z utratą wielu ważnych kompetencji, części samodzielności oraz stosunkowo łatwą możliwości likwidacji uczelni, będzie to także swoistym szokiem dla miejscowych ośrodków.

W świetle doktryny prawa administracyjnego uprawnienia nadzorcze ministra wobec jednostki zdecentralizowanej jaką jest uniwersytet powinny być wykonywane niezwykle powściągliwie. W świetle ostatnich zmian ustawowych możemy jednak powiedzieć o stałym wzmacnianiu pozycji prawnej Ministra właściwego do spraw nauki i szkolnictwa wyższego, a także pozostałych organów szczebla centralnego Państwowej Komisji Akredytacyjnej i Rady Doskonałości Naukowej.

Uniwersytet staje się cząstką systemu administracji nauki i nauczania, a priorytety jego działania są obecnie określane w polityce naukowej uchwalanej przez Radę Ministrów. Skomplikowany system finansowania uzależniony jest od złożonego systemu punktowego i prowadzonej co pięć lat ewaluacji, który powinien mieć jasne oparcie w ustawie, a nie stosować akty wewnętrzne, pozostawiając niewielki margines swobody. Minister ma szereg skutecznych środków związanych przede wszystkim z zastosowaniem kryterium finansowania, ale też uprawnieniami do likwidacji uczelni. Szczególnie silne są oczywiście jego uprawnienia wobec 
uczelni niepublicznych i zawodowych, ale potężnym instrumentem okazuje się pozwolenie na utworzenie studiów na określonym kierunku, poziomie i profilu. Tak wielkie uzależnienie wykracza poza klasycznie rozumiany system nadzoru.

\section{Krytyczna diagnoza}

Czy w perspektywie ogromnej zmienności, panujących obecnie warunków zewnętrznych, rosnącej niepewności administrowania związanej z cyfryzacją administracji i gospodarki, ale także nauczania i nauki potrzebujemy jeszcze klasycznej formy uniwersytetu tak jak ją postrzegał i analizował Tadeusz Bigo? Czy rzeczywiście przyszłość należy do „roztapiania” istoty uniwersytetu w wielości wielu różnych rodzajach jednostek systemu szkolnictwa wyższego? Czy zastąpienie wręcz pojęcia uniwersytetu/politechniki pojęciem uczelni (uczelnia akademicka, zawodowa) jest właściwym kierunkiem zmian? W toku tej ewolucji instytucji edukacyjnych długo ostawał się uniwersytet jako starodawna, ale wciąż żywa konstrukcja, instytucja europejskiego dziedzictwa. Dzisiaj staje się ona po prostu — jak reguluje to nasza nowa ustawa — ,wyrazem zastrzeżonym”. Innym określeniem szczególnego rodzaju uczelni akademickiej spełniającej kryteria A+, A i B+, a także ustawowe kryteria dodatkowe. Również klasyczne zadania nauki i nauczania uniwersytetu „giną" wśród wielu nowych, różnorodnych, nakładanych na dawny tak przecież samodzielny zakład publiczny.

Sądzę, że należy sformułować krytyczną diagnozę. Obserwowane zmiany organizacji szkolnictwa wyższego wydają się późnym przejawem zastosowania przestarzałej już doktryny NPM, z typową dla tej doktryny przesadną wiarą w ekonomizację działania uczelni z jednej strony i pozbawioną limitów prywatyzacją z drugiej, wydaje się to owocem nowych tendencji recentralizacji poszukujących w ścisłym centralizowaniu zarządzania nauką lepszej realizacji zadań państwa i sprostania przyszłym wyzwaniom ${ }^{29}$. Tymczasem klasyczna konstrukcja zakładu samorządowego jako pewnej enklawy wewnętrznej autonomii i wolności badawczej oraz efektywnej postaci samorządu innego jednak niż samorząd terytorialny ma w sobie ogromny potencjał innowacji, ale także rozładowania napięć społecznych. Jest to samorząd nie tak ściśle związany z określonym terytorium, ale oparty na wyraźnym substracie osobowym i dobrowolnej przynależności, obdarzony zdolnością modyfikacji władztwa administracyjnego wobec swoich destynatariuszy i załatwianiem własnych spraw wspólnoty we własnym zakresie i na własną odpowiedzialność.

29 U. Stelkens, Good Administration and the Council of Europe, Oxford 2020, s. 753 n. 
W nowym świecie europejskiej transformacji cyfrowej, opóźniona w tym globalnym wyścigu Europa potrzebuje silnego impulsu innowacji. Impulsu, który wciąż jeszcze nie stał się, mimo Traktatu lizbońskiego, rzeczywistością. Realizacji tego europejskiego marzenia poszukiwano bardzo długo. Po pierwsze, w zasadniczym zwiększaniu europejskich wydatków na innowacje; takie myślenie ulega wzmocnieniu w ramach Europejskiego Planu Odbudowy. Po drugie, w zacieśnianiu związku szkół wyższych z gospodarką i zapisywaniu tego obowiązku uczelni bezpośrednio w ustawie. Mimo mnożenia podobnych zobowiązań (obowiązek w związku z praktyką społeczno-gospodarczą), poprawa w sensie przełomu od lat nie następuje. Mnożenie mierników, punktów, a nawet groźby swoistej degradacji uczelni nie spełniającej oczekiwań w tym zakresie okazuje się w praktyce kontrproduktywne, usztywnia bowiem i formalizuje badania w coraz bardziej zmiennym otoczeniu.

Nauka i w ogólności innowacje potrzebują nadal chronionych obszarów wolności i nieskrępowanej debaty. Wzmacnianie centralizacji, formalizacja planów i sprawozdań, utrudnia raczej krótkoterminową zmianę kierunków badań, akceptację błędów i porażek jako koniecznego etapu wielkich odkryć, elastyczność tworzenia i zamykania zespołu badawczego. Są to atrybuty niezbędne do działania w warunkach niepewności, których doświadczamy na przykład obecnie, nie tylko w związku z pandemią. Można stwierdzić, że rozwiązaniem może się okazać właśnie powrót do pierwotnej misji i koncepcji uniwersytetu, do jego prostej uniwersalnej struktury. Nie oznacza to oczywiście powrotu do uniwersytetu $\mathrm{w}$ jego postaci $\mathrm{z}$ lat dwudziestych XX wieku, likwidacji inkubatorów przedsiębiorczości czy start-upów przy uczelniach. W epoce zrównoważonego rozwoju - poszanowania praw człowieka, ery cyfrowej oraz konieczności działań zespołowych w nauce - będzie to już inny uniwersytet.

Należy jednak postulować zintensyfikowane badań nad pojęciem zakładu samorządowego, konstrukcji równie uniwersalnej jak samorząd terytorialny, który nie tylko w Europie przeżywa czas swojego rozkwitu. Nie jest to problem wyłącznie Polski. W słusznym dążeniu do zwiększenia efektywności i obniżenia kosztów budżetowych wprowadzono postępującą biurokratyzację zarządzania uniwersytetem, dyrektywnego kształtowania praw członków wspólnoty, uczonych i nauczających, w złudzeniu, że kuratela zewnętrznych podmiotów gospodarczych oraz wielkich korporacji wymusi postęp i poprawi ich finansowanie. Okazuje się jednak, uniwersytety w całej Europie, przytłoczone szczegółowością regulacji prawnej, mierników i sprawozdawczości, tracą swoją typowo europejską rolę krytycznej refleksji, koła zamachowego innowacji, a mogą stać się wręcz elementem „kapitalizmu inwigilacji” w znaczeniu nadanym przez Schoschanę Zuboff ${ }^{30}$.

30 S. Zuboff, Wiek kapitalizmu inwigilacji inwigilacji, Poznań 2020, s. 267 n. 


\section{Podsumowanie}

Reasumując, należy powrócić do konstrukcji zakładu publicznego w świetle obecnej teorii prawa administracyjnego; jak wskazuje Jan Zimmermann ${ }^{31}$, regulacja prawna zakładów publicznych nie jest ani spójna, ani uporządkowana; wyróżnić należy wśród nich zakłady tworzone w drodze ustawy i są to właśnie uniwersytety oraz inne państwowe szkoły wyższe (w świetle nowej ustawy należałoby powiedzieć raczej państwowe uczelnie). Szkoła wyższa według Zimmermanna należy do kategorii zakładu o ograniczonym zasięgu, wyznaczonym zarówno przez obowiązujące przepisy, jak i przez organy danego zakładu. Autor podkreśla ${ }^{32}$, że standardem demokratycznego państwa prawnego jest prawo do równego korzystania ze świadczeń zakładowych w zakładach publicznych, a miarkowanie dostępu (w przypadku szkoły wyższej) następuje ze względu na „fachową i specjalistyczną ocenę" kandydatów do zakładu; zakłada to bezstronność rekrutacji. W świetle zaproponowanej przez autora kategorii uniwersytety należy zaliczyć do zakładów samoistnych o największej samodzielności, posiadających statuty i regulaminy, wyposażone w autonomię zakładu publiczne (autonomia szkoły wyższej) - co zostaje określone jako „skrajna postać samodzielności zakładu”. Dawny dylemat tego, jak zaszeregować zakłady zbliżone do korporacji o wyjątkowo dużej samodzielności pozostaje nad aktualny. Eugeniusz Ochendowski stwierdzał wręcz, że przestają one już być zakładami administracyjnymi ${ }^{33}$; należy przypomnieć w tym miejscu propozycję Tadeusza Bigi zmierzającą do rozwiązania tego dylematu, gdyż dyskusja o różnicy zakładu publicznego i korporacji stale powraca w doktrynie. Bigo proponował pośrednią kategorię zakładu samorządowego, co pozwalało zniwelować ostre przeciwstawienie klasycznego zakładu publicznego, który nie jest prowadzony przez jego członków oraz działa w interesie publicznym, korporacji realizującej własne interesy. Zimmermann zdaje się przychylać do propozycji Ochendowskiego, stwierdzając, że jeżeli w danym zakładzie administracyjnym występuje zarządzanie przez użytkowników, wspólnota interesów użytkowników i pracowników zakładu, można już mówić o korporacji, a nie o zakładzie. Określa on wprost:

dobrym przykładem takiej sytuacji jest uniwersytet, w którym studenci mają czynne prawo wyborcze i inne uprawnienia oraz istnieje założenie wspólnoty nauczanych i nauczających (universitas), którzy powinni tworzyć rzeczywistą wspólnotę, czyli właśnie „mikrodemokrację”34.

31 J. Zimmermann, Prawo administracyjne, Warszawa 2018, s. 206-208.

32 Ibidem, s. 207.

33 E. Ochendowski, Pozycja prawna studenta uniwersytetu - użytkownik zaktadu publicznego, czy członek korporacji publicznej, [w:] Jednostka w demokratycznym państwie prawa, red. J. Filipek, Bielsko-Biała 2003, s. 455 n.

34 J. Zimmermann, op. cit., s. 208. 
Marek Wierzbowski wskazuje natomiast, że zakład administracyjny stanowi

względnie samodzielną, państwową jednostką organizacyjną, wyposażoną w trwałe wyodrębnione środki rzeczowe i osobowe, której podstawowym celem jest ciągłe, bezpośrednie świadczenie usług socjalnokulturalnych o szczególnym znaczeniu społecznym ${ }^{35}$.

I tu akcentowana jest względna samodzielność.

Dla Raszewskiej-Skałeckiej na pojęcie zakładu składają się wydzielenie środków i organów zarządu tymi środkami oraz trwałość tego wydzielenia, ale jak podkreśla autorka, dla spełnienia określonego celu także względna samodzielność organów powołanych do zarządzania tymi środkami, wreszcie wyposażenie organów zakładu w prawo nawiązywania stosunków administracyjnoprawnych z użytkownikami i to „w zakresie podstawowej działalności zakładu”36.

Wydaje się, że propozycja Tadeusza Bigi mimo upływu wielu lat od jej powstania najlepiej rozwiązuje dylemat uznania istnienia formy pośredniej między korporacją a klasycznym zakładem publicznym w formie zakładu samorządowego. Odnowa pojęcia zakładu — jako uznanej formy decentralizacji — może pozwolić na silniejsze ugruntowanie tego nietypowego zakładu oraz obronę jego wciąż uszczuplanej samodzielności, ponieważ

cały sens tworzenia zakładów ziszcza się właśnie w tym, aby pewnej gałęzi administracji nadać większą sprawność techniczną, ta zaś daje się osiągnąc tylko przy pewnej samodzielności fachowych organów zarządzających danym działem ${ }^{37}$.

Jeszcze w latach pięćdziesiątych XX wieku, w okresie PRL, Maurycy Jaroszyński podkreślał, że dla ustalenia istnienia zakładu istotne jest stwierdzenie wyodrębnienia i usamodzielnienia organizacyjnego ${ }^{38}$. Nawet $w$ latach sześćdziesiątych Gebert podkreślał, że zakład zostaje wyodrębniony w celu realizowania określonych zadań, których specyfika „wymaga samodzielnego kierownictwa"39.

Marek Elżanowski określał zakład administracyjny (wówczas państwowy) jako każdą względnie samodzielną państwową jednostkę organizacyjną wyposażoną w trwale wyodrębnione środki rzeczowe i osobowe, której podstawowym (statusowym) celem jest mający ciągły, wyspecjalizowany charakter bezpośrednie świadczenie usług socjalno-kulturalnych w dziedzinie określonej w akcie o jej utworzeniu ${ }^{40}$. Dostrzegamy tu także kwestię owej względnej samodzielności, na której koncentruje się debata.

35 M. Wierzbowski, Podstawowe pojęcia teoretyczne w nauce prawa administracyjnego, [w:] Polskie prawo administracyjne. Część I, red. J. Służewski, Warszawa 1985, s. 79.

36 R. Raszewska-Skałecka, Koncepcja zakładu administracyjnego w polskiej nance prawa administracyjnego, „Przegląd Prawa i Administracji” 68, 2005, s. 192.

37 T. Bigo, op. cit., s. 179.

38 Polskie prawo administracyjne. Część I, red. M. Jaroszyński, Warszawa 1952, s. 176.

39 S. Gebert, Komentarz do ustawy o radach narodowych, Warszawa 1964, s. 118-120.

40 M. Elżanowski, op. cit., s. 66-67. 
Powróćmy jednak do debaty o zakładzie po roku 1989. Sławomir Fundowicz, pisząc o zakładach publicznych ${ }^{41}$, akcentował prawne upodmiotowienie i zorganizowanie, wyposażenie we władzę zwierzchnią, ale także „miarodajny wpływ podmiotu tworzącego, jeżeli nie jest to ustawowo wyłączone”. Charakterystyczne było ujęcie przez autora substratu osobowego w sposób różny od korporacji. Fundowicz wyróżniał grupy osób, które „wspierają skuteczność” zakładu, czyli użytkowników, jednak nieuprawnionych do prawnego wpływania na „skuteczność organów organizacji” i o pasywnej pozycji. Popieranie interesów destynatariuszy jest przedmiotem celu organizacji, a nie celem. Wyraźne jest też ostre odróżnienie korporacji i zakładu.

Jest rzeczą niezwykle charakterystyczną ogólnie dość duża powściągliwość doktryny w rozważaniu samodzielności zakładu. W tym zakresie Tadeusz Bigo wyprzedzał swoje czasy, przede wszystkim przez trafne rozpoznanie, że uniwersytet, jeżeli ma zachować autonomię oraz elementy unikalnej samodzielności uczelni będące fragmentem dziedzictwa kultury europejskiej, powinien być ujmowany jako zakład samorządowy, w którym użytkownicy (destynatariusze), sięgając ponownie do określenia Fundowicza, nie tylko nie są pasywni z mocy prawa, ale są aktywnymi, współkształtującymi elementami wspólnoty. Przy omawianiu w literaturze unikalności dziedzictwa europejskiego bardzo często akcentuje się właśnie uniwersytet jako ośrodek autonomiczny debaty i wolnych badań. We wszystkich cywilizacjach pozaeuropejskich, chińskiej, japońskiej czy arabskiej mamy do czynienia $\mathrm{z}$ wiekowymi szkołami wyższymi, często o ogromnym znaczeniu dla rozwoju tych cywilizacji. Unikalnym wynalazkiem Europy było właśnie owo połączenie w uniwersytecie substratu osobowego, materialnego i odpowiedniej części samodzielności oraz autonomii akademickiej, ułatwiającej krytyczne podejście do badań. Częścią tej unikalnej formuły było także zawsze współwystępowanie w ramach uczelni organów kolegialnych i jednoosobowych z wyboru.

Podobnie stało się z „wynalazkiem” samorządu terytorialnego. Wspólne dla dziejów obu instytucji było jednak także powstałe w XX wieku pod wpływem thatcheryzmu przekonanie o konieczności pilnej ekonomizacji i prywatyzacji szkół wyższych. Trendem dodatkowym w duchu NPM było deprecjonowanie wewnętrznych, demokratycznie wybieranych organów kolegialnych jako spowalniających procesy decyzyjne w szkole wyższej, a także w samorządzie.

W polskiej doktrynie prawa administracyjnego przełomu XX i XXI wieku prawna forma organizacyjna zakładu była określana krytycznie ${ }^{42}$, choć przesadna wydaje się ocena, że aktywność funkcjonowania zakładu podlegała wówczas powszechnej krytyce. Podnoszono wtedy, że przykłady świadczenia usług niematerialnych przez zakłady prywatne, na przykład szkoły wyższe, potwierdzają

41 S. Fundowicz, Zakłady publiczne, [w:] Prawo administracyjne ustrojowe. Podmioty administracji publicznej, red. J. Stelmasiak, J. Szreniawski, Bydgoszcz-Lublin 2002, s. 175 n.

42 Z. Czarnik, J. Posłuszny, Rozdział VII. Zakład publiczny, [w:] System Prawa Administracyjnego, t. 6, s. 56 . 
użyteczność prywatyzacji; panowało przekonanie, że mogą być one wykonywane sprawnie i lepiej przez zakłady prywatne. Pozytywnie należy ocenić fakt, że polska doktryna prawa administracyjnego nie poddała się w tym zakresie panującym wówczas trendom. Przykładowo autorzy poruszający tą kwestię w Systemie Prawa Administracyjnego ${ }^{43}$ podkreślali mocno, że państwo nie może zrzec się odpowiedzialności za wykonywanie wielu ważnych zadań administracji świadczącej ani nawet dzielić się tą odpowiedzialnością z podmiotami prywatnymi, a sfera usług publicznych, ze względu na swą specyfikę, nie może zostać poddana zasadom rynkowym. Czytamy wręcz o odporności na wpływy rynkowe i konieczności zapewnienia ciągłości świadczenia usług; chodzi w szczególności o zapobieżenie temu, aby odpowiedzialność państwa za wykonywanie konstytucyjnych zadań publicznych stała się fikcją; do tej kategorii autorzy zaliczają także edukację. I chociaż nie odrzucają całkowicie prywatyzowania zakładów publicznych, świadczących usługi niematerialne, stwierdzają, że nie można im przypisywać znaczącej roli, nie wyklucza to natomiast swoistej ekonomizacji działania zakładów publicznych. Ta przenikliwa powściągliwość wobec prywatyzacji, zwłaszcza zakładów samorządowych zasługuje na pozytywną ocenę. Nie sprawdziła się jednak prognoza, że docelowo bez znaczenia będzie charakter państwowy, samorządowy czy prywatny zakładu, a najważniejsza okaże się standaryzacja usług. Samodzielność i wewnętrzny samorząd zakładu, a także władztwo zakładowe pozostają w moim przekonaniu cennymi w odniesieniu do uniwersytetu wartościami ${ }^{44}$.

\section{Bibliografia}

Biernat S., Prywatyzacja zadań publicznych: problematyka prawna, Warszawa-Kraków 1994.

Bigo T., Związi publicznoprawne w świetle ustawodawstwa polskiego, Warszawa 1928.

Bloom A., Umyst zamknięty. O tym, jak amerykańskie szkolnictwo wyższe zawiodto demokracje i zubożyło dusze dzisiejszych studentów, Poznań 2007.

Cieślik Z., Gredka-Ligarska I., Gwoździewicz-Matan P., Lipowicz I., Matan A., Zeidler K., Komentarz do ustawy o muzeach, Warszawa 2021.

Czarnik Z., Posłuszny J., Rozdział VII. Zakład publiczny, [w:] System Prawa Administracyjnego, t. 6. Podmioty administrujące system prawa administracyjnego, red. R. Hauser, Z. Niewiadomski, A. Wróbel, Warszawa 2011.

Dobkowski J., Podmiotowość prawna samorzadu terytorialnego w świetle poglądów Jerzego Karola Panejki, [w:] M. Stec, K. Małysa-Sulińska, Podmiotowość samorządu terytorialnego ustrojowe pytania i dylematy, Warszawa 2020.

Elżanowski M, Zakład państwowy w polskim prawie administracyjnym, Warszawa 1970.

43 Ibidem.

44 T. Skoczny, Z zagadnień teorii i metod, prawne cele ingerencji, [w:] Obywatel wobec ingerencji współczesnej administracji, red. J. Boć, Wrocław 1985; S. Biernat, Prywatyzacja zadań publicznych: problematyka prawna, Warszawa-Kraków 1994. 
Fundowicz S., Zaktady publiczne, [w:] Prawo administracyjne ustrojowe. Podmioty administracji publicznej, red. J. Stelmasiak, J. Szreniawski, Bydgoszcz-Lublin 2002.

Gebert S., Komentarz do ustawy o radach narodowych, Warszawa 1964.

Kasznica S., Polskie prawo administracyjne, Warszawa 1947.

Klonowiecki W., Zakład publiczny w prawie polskim studium prawno-administracyjne, Lublin 1933.

Mayer O., Deutsches Verwaltungsrecht, Leipzig 1895.

Ochendowski E., Pozycja prawna studenta uniwersytetu - użytkownik zaktadu publicznego, czy członek korporacji publicznej, [w:] Jednostka $w$ demokratycznym państwie prawa, red. J. Filipek, Bielsko-Biała 2003.

Ochendowski E., Zakład administracyjny jako podmiot administracji państwowej, Poznań 1969.

Polskie prawo administracyjne. Część I, red. M. Jaroszyński, Warszawa 1952.

Raszewska-Skałecka R., Koncepcja zakładu administracyjnego w polskiej nauce prawa administracyjnego, „Przegląd Prawa i Administracji” 68, 2005.

Raszewska-Skałecka R., Zaktady, [w:] Tadeusz Bigo o administracji i prawie administracyjnym refleksje wrocławskiej szkoły administratywistycznej, red. T. Kocowski, P. Lisowski, M. Paplicki, Wrocław 2020.

Skoczny T., Z zagadnień teorii i metod, prawne cele ingerencji, [w:] Obywatel wobec ingerencji współczesnej administracji, red. J. Boć, Wrocław 1985.

Stahl M., Zagadnienia ogólne, [w:] System Prawa Administracyjnego, t. 6. Podmioty administrują$c e$, red. R. Hauser, Z. Niewiadomski, A. Wróbel, Warszawa 2011.

Stelkens U., Good Administration and the Council of Europe, Oxford 2020.

Wasiutyński B., Samorzą uniwersytecki, „Przegląd Prawa i Administracji” 4, 1926.

Wierzbowski M., Podstawowe pojęcia teoretyczne w nauce prawa administracyjnego, [w:] Polskie prawo administracyjne. Część I, red. J. Służewski, Warszawa 1985.

Zakowicz I., Idea uniwersytetu Wilhelma von Humboldta - kontynuacja czy zmierzch?, „Ogrody Nauk i Sztuk" 2012, nr 2.

Zimmermann J., Prawo administracyjne, Warszawa 2018.

Zuboff S., Wiek kapitalizmu inwigilacji inwigilacji, Poznań 2020.

\section{The Evolving Perception of the University Systemic Status against the Background of Tadeusz Bigo's Views}

\section{Summary}

The aim of the study is to consider the evolution of the University institution against the background of recent changes in the legal status in this area, in confrontation with the classic form of a self-governing independent establishment, a construction developed in 1928 by Tadeusz Bigo. The university was then perceived as a public establishment, a community of scholars and learners. The fascination with efficiency, managerial approach typical for corporations, in the final years of the 20th century, meant a gradual departure from the vision of the University as a space of freedom, academic autonomy, creativity, and independence - a recognised form of decentralisation.

The paper points out, against the background of differing doctrine views, the form of a public establishment as the gradual formation of the prevailing view of the university in this respect. The legal effects of moving away from the universal university construction to the future dualism of 
academic and vocational universities were analysed. Progressive limitation of their autonomy takes place, among others, through the multiplication of measures, indicators, and evaluation, as well as standardization, formal scoring of academic achievements. In the Polish language, university, in contrary to Tadeusz Bigo's concept, has become a "reserved word" for the name of one from among many types of universities. The conclusion of the article is a conviction about the theoretical bearing and further practical usefulness of the discussed universal construction of the university as an intermediate form between corporation and administrative establishment once proposed by Tadeusz Bigo. This indicates deficits of new legislative solutions in relation to future tasks of the university in times of management in conditions of uncertainty and a key role of creating an environment conducive to creativity and innovation.

Keywords: university, public establishment, administrative establishment, local government establishment, decentralization. 